\title{
The Elite Deliberative Democratic Model In The Public Policy Formulation For Madrasah Diniyyah (Islamic Non Formal School) Development In East Java, Indonesia
}

\author{
Ismail \\ STAI Nazhatut Thullab Sampang \\ yajlisismail@gmail.com \\ Moh. Wardi \\ STAI Nazhatut Thullab Sampang \\ mohwardi84@gmail.com
}

\begin{abstract}
This research intend to discuss about public policy from East Java province government to improve the quality of Islamic religious education. The results of this study were: (1) East Java Provincial Government used policy formulation model in the name "elite deliberative democratic ". A policy formulation model that combines several theories of policy formulation, there are elite, deliberative theory, and democratic theory. (2) The policy formulation was done through several stages: They are reading of the reality; preparation of the general policy of long-term development; arrangement of short-term development policy; the preparation and stipulation of Regional Regulations, and the Governor Regulation on Translation of APBD; (3). The government of East Java province has under graduate Scholarship program (S.1) for Madrasah diniyyah teachers.
\end{abstract}

Keywords: Public policy; formulation; madrasah diniyyah; elite deliberative; democratic; under graduate program; east java; Indonesia;

\begin{abstract}
Abstrak
Penelitian ini bermaksud membahas tentang kebijakan publik dari pemerintah provinsi Jawa Timur untuk meningkatkan kualitas pendidikan agama Islam. Hasil penelitian ini adalah: (1) Pemerintah Provinsi Jawa Timur menggunakan model perumusan kebijakan dengan nama "elite deliberative demokratis". Sebuah model perumusan kebijakan yang menggabungkan beberapa teori perumusan kebijakan, ada elit, teori deliberatif, dan teori demokrasi. (2) Perumusan kebijakan dilakukan melalui beberapa tahap: Mereka membaca realitas; persiapan kebijakan umum pembangunan jangka panjang; pengaturan kebijakan pembangunan jangka pendek; persiapan dan penetapan Peraturan Daerah, dan Peraturan Gubernur tentang Penerjemahan APBD; (3) Pemerintah provinsi Jawa Timur memiliki program sarjana (S.1) untuk guru Madrasah diniyyah
\end{abstract}

Kata kunci: formulasi; kebijakan publik; madasah diniyah; elit; deliberative; demokratis; jawa timur; Indonesia; 


\section{Introduction}

It is believed that the application of the centralistic pattern has made the wheels of government and development less effective and efficient; prone to leaks; causing regional inequality and injustice; forcing uniformity; disabling potential and regional characteristics; difficult quality control (quality control) and quality assurance (quality assurance); kill local government creativity; and hamper community participation 1.

Decentralization is the transfer of government authority by the Government to the autonomous regions to regulate and manage government affairs within the system of the Unitary State of the Republic of Indonesia.2 While the autonomous Region, hereinafter referred to as the region, is a legal community unity which has territorial boundaries that are authorized to regulate and manage the affairs of the government and the interests of local people according to their own initiative based on the aspirations of the people in the system of the Unitary State of the Republic of Indonesia 3.

Concretely when the Act is published No. 23 of 2014 and the latest amendment with the Act No. 9 of 2015. This law expressly indicates what should be done by the Central Government and what is the authority of the Provincial Government and district/city As stated in article 5 that: "The implementation of Government Affairs as referred to in paragraph (2) in the Region shall be implemented based on the principle of Decentralization,

1 M. Sirozi, Politik Pendidikan: Dinamika Hubungan antara Kepentingan Kekuasaan dan Praktik Penyelenggaraan Pendidikan (Jakarta: Rajawali Press, 2010).

2 Act. No. 32 of 2004 on Regional Government. Article 1. According to Suryadi and Budiman in Riant Nugroho: With the delivery of education management, it means that the Regional Government has the freedom to manage and nurture education independently, in order to achieve the target of basic and secondary education development programs. This authority covers the various stages since decision making, programming, implementation, program monitoring, up to the procurement of educational facilities (Nugroho, 2008: 28-29).

3 Riant Nugroho, Kebijakan Pendidikan yang Unggul: Kasus Pembangunan Pendidikan di Kabupaten Jembrana 2000-2006 (Yogyakarta: Pustaka Pelajar, 2008). 
Deconcentration and Co-Administration" 4. Governmental affairs of education is a joint matter, meaning that for education there are parts that are done by the center and there is decentralized part (Zainal, 2013: 254). The occurrence of decentralization in government affairs is certainly expected to have a positive impact on the achievement of the ideals of life of the nation and state, namely promoting public welfare and educating the life of the nation, and that education is an indispensable tool for social and economic development 6. Democracy in education means that educational processes and educational systems are built to be realized independently and responsibly 7.

In the context of the involvement of local government in the development of madrasah there is an interesting argument presented by Nur Ahid. According to him, referring to the Act. No. 22 of 1999 on Regional Government, that in the explanation of article 7 paragraph 1 that is; "Particularly in the religious field, some of its activities can be assigned by the Central Government to the Regional Government as an effort to increase regional participation in developing religious life," he said, meaning that religious affairs are not autonomy, but still gives the opportunity of assigning certain fields (religious education) to the regions 8.

The existence of a dichotomy view on government policy implementation. occurs in schools and madrasah, also in the state and the private sector. And the most felt for this distinction is a private madrassah, or an Islamic educational institution founded and managed by the community. For whatever reason, the

4 Republic of Indonesia, “Act. No. 23 Year 2014” (2014).

5 Fourth paragraph of the 1945 Constitution. "Then to form an Indonesian State that protects the entire Indonesian nation and the entire blood of Indonesia and to promote the general welfare, educate the life of the nation, and participate in the implementation of world order based on freedom, eternal peace and social justice...

6 Veithzal Rivai Zainal dan Fauzi Bahar, Islamic Education Management: dari Teori ke Praktek (Jakarta: Rajawali Press, 2013).

7 H.A.R. Tilaar, Standarisasi Pendidikan Nasional: Suatu Tinjauan Kritis (Jakarta: Rieneka Cipta, 2006).

8 Nur Ahid, "Problem Pengelolaan Madrasah Aliyah dan Solusinya," Islamica2 4, no. 2 (2010).

9 Azyumardi Azra, Pendidikan Islam: Tradisi dan Modernisasi di Tengah Tantanngan Millenium III (Jakarta: Kencana Prenadamedia Group, 2014).. 
implementation of government policy is still not proportional. Certainly private Islamic educational institutions - consisting of MI, MTs, MA, PTKIS, pesantren, Madrasah diniyyah10 - are still far from real educational democracy.

For private madrasah - almost certainly - to receive education funds sourced from APBN only in the form of School Operational Assistance (BOS) is nothing else.11 Meanwhile, to meet all the needs, Madrasah diniyyah must struggle to earn contribution and donation from the society that is not clear. The irony is that the demand for private madrasah is not different from the land either from government regulation or from public expectation. We can see how the government enforces an external quality assurance system by establishing the National Accreditation Board/Provincial School/Madrasah (BAN/P-S/M) 12. In the process of accreditation, all must be obedient, submissive and submissive mercilessly against the wishes of the government contained in the instrument of accreditation.13

In 2006, East Java Provincial Government made an education policy directly affecting Madrasah Diniyyah, the policy of quality improvement program of Madrasah Diniyyah teachers,14 followed by the policy of Madrasah Diniyyah Implementation Program and Private Teacher (BPMDGS).15 When almost

10 Republic of Indonesia, "National Education System" (2003).

11 There are other forms of assistance, such as sarpras aids, auxiliary teachers, and others, but they are very limited.

12 Government of Indonesia, "National Education Standart" (2005).

13 Suppose Permendiknas No. 11 Year 2009 on the Criteria and Tools of Elementary School Accreditation / Madrasah Ibtidaiyah (SD / MI).

14 Furthermore, the Quality Improvement Program of Madrasah diniyah Teachers is commonly referred to as Madin Scholarship S1. The total budget of East Java Province APBD in the implementation of this program from 2006 to 2015 amounted to Rp. 78.5 billion. While Madin Guru who has received the program as many as 9703 people, with the help of each person of Rp 8.5 million. In www.beritalima.com> Region> East Java.

15 Assistance for the Implementation of Diniyyah and Private Teachers (BPMDGS) is a funding for education santri/study/student of Diniyyah Ula/Wustho, A/B Packages and A/B Packages Pondok Pesantren, Ustadz/Guru Diniyyah Ula/Wustho and Private Elementary School Teachers/MI/SDLB/SLB/Salafiyah Ula/SMP/MTs/SMPLB/Salafiyah Wustho. See East Java Provincial Education Office, Technical Guidance for 
nationally is unwilling and unable to make policies that touch non formal Islamic religious education (madrasah diniyyah), it turns out that the East Java Provincial Government bravely and confidently launched a program that is very eagerly awaited by the community - at least by stakeholders diniyyah education in East Java. Even in other Provincial Governments, still sporadic, not systematic like the policy of East Java Provincial Government.16 The author believes that this policy is a political product in East Java involving many parties.

\section{Public Policy Formulation of Madrasah diniyyahDevelopment in East Java}

According to William N. Dunn, policy formulation takes place in three phases, namely: the agenda setting phase, policy formulation and policy adoption 17. Agenda preparation means the decision maker determines the issues that are the focus of the study in policy analysis. There may be a lot of issues that develop in the community, but not all have urgency that requires the birth of a policy, so the decision maker should be able to arrange every agenda that wants to be solved from the problems faced. Policy formulation means that stakeholders are prepared to make several alternative actions that are deemed to solve the current problem, or the achievement of a particular goal. Policy adoption means that once the stakeholders have an alternative action or step, then from some of these alternatives are selected one that is considered as the most appropriate step for problem solving.

That the formulation of development policy in East Java post-reformation started from the establishment of Long Term Development Plan Area (RPJPD) East Java Province. The RPJPD of East Java Province is first stipulated in Regional Regulation

Diniyyah and Private Teachers in 2014. Surabaya: tp, 2014. BPPDGS is more familiar with BOSDA Madin.

16 According to the researcher systematization of this policy, because siphoning Provincial APBD is not small and requires the district/city government involved at least $1 / 6$ of the province budget.

17 William N. Dunn, Pengantar Analisis Kebijakan Publik (Yogyakarta: Gadjahmada University Press, 2000). 
Number 1 Year 2009 concerning the Long Term Development Plan of the Region (RPJPD) of East Java Province 2005-2025.18 In this Regional Regulation it is explained that the East Java Province Long Term Development Plan Year 2005-2025 hereinafter referred to as Provincial RPJPD is a regional development planning document for a period of 20 (twenty) years from 2005 to 2025 . Furthermore, from the RPJPD it is known that East Java Province compiled a series of strategic issues, vision, mission and development strategy of East Java Province. Analysis of strategic issues is an analysis of the threat of food crisis; energy crisis; globalization and free trade; poverty, inequality, unemployment and quality of human resources; as well as climate change and global warming.19

Then in article 4 explained that the vision of East Java development is making East Java as the center of leading agribusiness, global competitive and sustainable to prosperous and prosperous East Java. Vision to realize prosperous East Java and morals is what cannot be separated from the area of education, both education in general and diniyyah education (Islamic religion) in particular, so that efforts to achieve the vision through the implementation of development missions. The East Java development mission in the long term that has a significant correlation with education is to realize a reliable human resources, noble and cultured.20 Of course the implementation of the mission requires the right strategy. Therefore, the Province of East Java set the main strategy of development related to human resources and noble morals, namely through equity and sustainable economic growth and quality, human development and equity of infrastructure development based on bureaucracy reform, law and

18 Regional Regulation Number 1 Year 2009 on Long Term Development Plan of the Region (RPJPD) of East Java Province Year 2005-2025, article 1.

19 Regional Regulation Number 1 Year 2009 on the Long Term Development Plan of the Region (RPJPD) of East Java Province Year 20052025, article 3.

20 Regional Regulation Number 1 Year 2009 on Long Term Development Plan of the Region (RPJPD) of East Java Province Year 2005-2025, article 5. 
political supremacy.21 The mission was developed into an effort directed towards the development of education, the development of religious life; cultural development, youth and sports development, women's empowerment, and development and consolidation of national identity.22 It is this mission that will not be separated from the involvement of religious education.

East Java established a policy of religious life development directed to establish the function and role of religion as a moral and ethical foundation in development, as well as the formation of noble character, fostering work ethic and appreciate achievement.23 Therefore, according to the researcher, that East Java Province has established its policy in development through the field of religious life. The agenda in the direction of this policy includes: 1) improving the quality of internal harmony and interreligious. 2) strengthening the quality of religious life services through the management and development of religious implementation facilities. 3) strengthening the quality of religious and religious education on the path, type and level of education, and 4) improving the quality and capacity of religious institutions.24 The agenda points of policy that will continue to be the basis of policy of East Java Provincial Government in the field of religious life until later in the year 2025. While the actors 25 in

${ }_{21}$ Regional Regulation Number 1 Year 2009 concerning the Long Term Development Plan of the Region (RPJPD) of East Java Province Year 20052025, Article 6.

22 Regional Regulation Number 1 Year 2009 on Long Term Development Plan of the Area (RPJPD) of East Java Province Year 2005-2025, Article 7.

23 Appendix to Regional Regulation Number 1 Year 2009 on Long Term Development Plan of the Region (RPJPD) of East Java Province Year 20052025, 39.

24 Appendix to Regional Regulation Number 1 Year 2009 on Long Term Development Plan of the Region (RPJPD) of East Java Province Year 20052025, 39.

25 Public policy actors are also referred to by Leo Agustino as Policy Maker. The policy-making officer is a person who has the legitimate authority to participate in the formulation to public policy decisions. Policymakers are divided into primary policy makers and secondary policy makers. Primary policy-makers are actors or stakeholders who have directional institutional authority to act. While secondary policymakers are mandatory parties of secondary policy-makers in policy formulation and determination Leo Agustino, Dasar-Dasar Kebijakan Publik (Bandung: Alfabeta, 2012).. 
the preparation of RPJPD in 2005-2025 is composed of executive elements (East Java Provincial Government) and legislative (DPRD East Java Province).

After the stipulation of RPJPD in 2005-2025, as planned development stage, East Java Provincial Government shall prepare Regional Medium Term Development Plan (RPJMD) of East Java Province in four stages: First Phase (2005-2009); Second Stage (2010-2014); Third Stage (2015-2019); Phase Four (2020-2024),26 then in 2016 this has been entered in the construction of the third stage (2015-2019). Therefore, the East Java Provincial Government prepares its RPJMD for 2014-2019, as set forth in the East Java Provincial Regulation No. 3 of 2014 on the Medium Term Development Plan of East Java Province Year 2014-2019. In this RPJMD, East Java Province has a general policy and development program with the aim of increasing the quality of education, and educational personnel. In the effort to improve the quality of education and education personnel, conducted with strategies to improve the quality and education services. The significant policy direction with diniyyah education is improving the quality of boarding school education through the help of the implementation of diniyyah education, and private teachers.27 As RPJPD, RPJMD is a joint policy formulation between executive (East Java Provincial Government) and legislative (East Java Provincial DPRD).

Furthermore, the Provincial Government shall prepare a Regional Government Work Plan (RKPD) which is a regional planning document for a period of 1 (one) year. This document is a translation of the RPJMD in each year of the annex. RKPD is an annual development document prepared in order to ensure consistency and synchronization between planning, budgeting, implementation, and supervision, and is an integral part of the drafting stage of the RAPBD, which comprises from RKPD,

26 Regional Regulation Number 1 Year 2009 on the Long Term Development Plan of the Region (RPJPD) of East Java Province Year 20052025, Article 8.

27 Attachment of Regional Regulation of East Java Province Number 3 Year 2014 on East Java Medium Term Development Plan Year 2014-2019, 407. 
KUA, PPAS, and RKA SKPD budget work plan.28 In the context of development policy of Madrasah diniyyahin East Java, for example can be seen in RKPD Year 2015, East Java Provincial Government set the flagship program (icon Governor), among others Bosda Madin and equitable distribution of educators. From these two eminent programs, there are programs whose nomenclature is a compulsory nine-year basic education program and a quality improvement program for educators and education personnel.29

After the RKPD is fully then further policy formulation is in the process of formulating the General Policy of Regional Budget (APBD).30 The preparation of KUA began with the drafting of KUA by the Governor of East Java assisted by the Regional Secretary as the coordinator of the Local Government Budget Team (TAPD). ${ }_{31}$ KUA draft is arranged according to data owned by all SKPD. Next after the draft KUA compiled then East Java Governor submit it to East Java Provincial DPRD for discussion before being passed into KUA. KUA draft discussion is done by TAPD as the executive party with Budget Committee (Panggar) as the legislative party. The KUA draft, which was discussed by the East Java provincial and executive legislative bodies, included the targets of measurable performance achievements of programs to be implemented by the local government for each local government affairs accompanied by projected regional revenues, the allocation of regional expenditure, the source and use of

28 Enclosure of Governor Regulation Number 23 Year 2014 on Regional Development Plan of East Java Province Year 2015, 4.

29 Enclosure of Governor Regulation No. 23 of 2014 on Regional Development Plan of East Java Province Year 2015, 209.

30 The APBD General Policy (KUA) is a document that contains policies on the areas of income, expenditure, and financing, and its median assumption for a period of 1 (one) year.

31 The Local Government Budget Team (TAPD) is a team formed with the decision of the regional head that is led by the regional secretary and has the task of preparing and implementing the regional head in the framework of APBD arrangement whose members consist of local planner officials, PPKD and other officials as needed. 
financing which is accompanied by the underlying assumptions.32 From the discussion between the two parties then obtained an agreement, and the agreement was then called the General Policy of the Regional Budget (KUA). So that was still a draft after agreed by the provincial government with the DPRD then be KUA.

Then, based on the existing KUA, the provincial government drafted the PPAS. Priorities and Fixed Budget Ceiling (PPAS) is the design of priority programs and benchmarks of the maximum budget limit given to SKPD for each program as a reference in the preparation of RKA-SKPD before it is agreed with the DPRD. As explained in the Regulation of the Minister of Home Affairs Number 13 of 2006 and its amendment, that the governor shall prepare the PPAS through 3 (three) stages. First, the stage of determining the priority scale for compulsory and optional affairs. Second, the stage determines the sequence of programs for each of the affairs. And third, the stage of arranging the temporary budget ceiling for each program. After the PPAS is completed, the governor then submits it to the Provincial DPRD and deliberations are discussed between TAPD and the provincial legislative committee. In this discussion there will be a deep discussion, because the provincial DPRD budget committee checks the PPAS proposed by the government. Obviously to the draft proposed by the provincial government, the DPRD will provide input, correction or even criticism if deemed necessary. However, the spirit in this discussion is to produce a "pro-people" APBD. After the discussion and discussion was completed then the agreement was reached between the provincial government and the provincial DPRD, then the PPAS was changed to Budget Priority and Budget (PPA). Budget Priorities and Budget (PPA) is a prudential and minimum budget limit program given to SKPD for each program as a reference in the preparation of RKA-SKPD after it has been agreed with DPRD. Both KUA and PPA agreed by the provincial government and provincial parliament are

32 Regulation of the Minister of Home Affairs Number 13 of 2006 concerning Guidelines on the Management of Regional Ecosystems, Article 84 as amended the latest by Permendagri Number 21 of 2011. 
evidenced by a memorandum of understanding on KUA-PPA signed by the Governor and the head of the DPRD.

The next stage in the process of formulating the policy of East Java Provincial Government after the approval of KUA PPA is the preparation of Work Plan and Budget of Regional Working Unit (RKA-SKPD). RKA-SKPD is a planning and budgeting document containing income plans, expenditure plans, program spending plans and SKPD activities, as well as a financing plan as the basis for the preparation of APBD. RKA-SKPD was prepared by the head of SKPD based on guidance issued by governor and KUA, PPA and account code.

The formulation of provincial government policy for the next stage is the preparation and determination of APBD. APBD preparation starts after RKA SKPD has been completed from all SKPD and finished reviewed by TAPD. At this stage it begins with the preparation of the draft Local Regulation (Raperda) on APBD and the Governor Regulation Draft (Rapergub) on the Translation of APBD. Raperda APBD which has been prepared by PPKD submitted to the governor and then carried out socialization to the community. In the process of socialization Rapeda APBD aims to be known by the public and get input from the community in order to complete the necessary improvements.

After the socialization, Raperda APBD then delivered by the governor to the provincial parliament 33 for discussion. Discussion of Raperda APBD implemented by Provincial DPRD according to field / commission in DPRD. 34 Through the commissions that become the legislative instrument,35 the provincial parliament

33 The role of Provincial DPRD in the stipulation of provincial regulation is the implementation of provincial DPRD function in; formation of local regulations, budgets, and supervision. Law Number 23 of 2014 regarding Regional Government article 96 as amended most recently by Law Number 9 Year 2015.

34 Provincial DPRD has 5 (five) commissions, namely commission A in charge of government, commission B in charge of economy, commission $\mathrm{C}$ in charge of finance, commission $\mathrm{D}$ in charge of development, and commission $\mathrm{E}$ in charge of people's welfare.

35 According to Law No. 23 of 2014 on Regional Government article 110 as amended most recently by Law Number 9 Year 2015, the provincial DPRD fittings consist of: heads, deliberation bodies, commissions, provincial 
conducts a discussion on the regional budget draft proposed by the governor. Submission of RAPERD by the governor to the leadership of the provincial DPRD is carried out simultaneously with the delivery of finance memorandum in a plenary session of the provincial DPRD.

DPRD Province Committees discussed the RAPDD by referring to the PPA KUA previously agreed upon by the Provincial DPRD and the governor. If the Provincial DPRD considers it necessary to obtain further explanation of APBD content, the DPRD will bring SKPD heads through the governor and TAPD. In the committee and SKPD meetings this is the real budget discussion. It is said that, because in the meeting of the discussion of APBD in this commission, the members of the DPRD will question in detail about every budget listed and also SKPD will provide the widest possible explanation so that the proposed budget draft can be approved by the provincial DPRD.

If the discussion of APBD at the commission level is over, then the result of the commission meeting is brought to the plenary of the provincial DRPD, to get a response and also approval from all factions in the provincial DPRD. Therefore, in this plenary session there is a session provided for each fraction of the Provincial DPRD to submit its response to the draft APBD submitted by the governor. And if in this plenary session according to the fraction in the Provincial DPRD, there is still a part of regional budget draft that must be completed by the governor, then the Regional Budget draft will be returned to the governor for improvement and refinement, and will go through this process from the beginning. However, if the majority or even the entire faction in the Provincial DPRD agrees that the draft APBD submitted by the governor is considered complete, then the approval process between the DPRD and the governor is carried out.

On the basis of mutual agreement between the Provincial DPRD and the governor on the Regional Budget Bill, then the governor will prepare a rapergub on the translation of APBD. Rapergub translation of APBD then submitted to the provincial

legislative bodies, budget bodies, honorary bodies, and other fittings required and formed by a plenary meeting. 
DPRD for approval. After the Rapergub translation of APBD get approval from the Provincial DPRD, then raperda APBD and Rapergub translation of APBD submitted to the Ministry of Home Affairs for evaluation. 36 Within the prescribed time the Ministry of Home Affairs will deliver the results of the evaluation to the provincial government. If the result of the evaluation states that the RAPPD and the municipality budget should be improved then the provincial government together with the provincial DPRD will make improvements as the result of the evaluation. And if the result of evaluation indicated that raperda APBD and rapergub elaboration of APBD has been in accordance with the provisions in effect then the next is the governor to determine the draft Regional Regulation of Regional Budget (APBD) into regional regulation and the budget for the translation of $A P B D$ into the regulation of APBD. Thus the process of policy formulation in the government of East Java Province, as a result of the analysis of the data the researchers obtained, both data interviews with some parties in the government and East Java provincial DPRD, as well as document data obtained by researchers. So thereby finished the process of policy formulation and will then enter the phase of implementation or implementation of the policy. Here is a picture of the flow and role of Madin's policy actors Coordinate Line.

36 Evaluation as intended aims to achieve harmony between regional policy and national policy, the harmony between public interest and the interests of the apparatus and to examine the extent to which the provincial APBD does not conflict with the public interest, higher regulations and / or other regional regulations established by the province concerned. Regulation of the Minister of Home Affairs Number 13 of 2006 concerning Guidelines on Regional Financial Management Article 110 as amended the latest by Regulation of the Minister of Home Affairs Number 21 of 2011. 


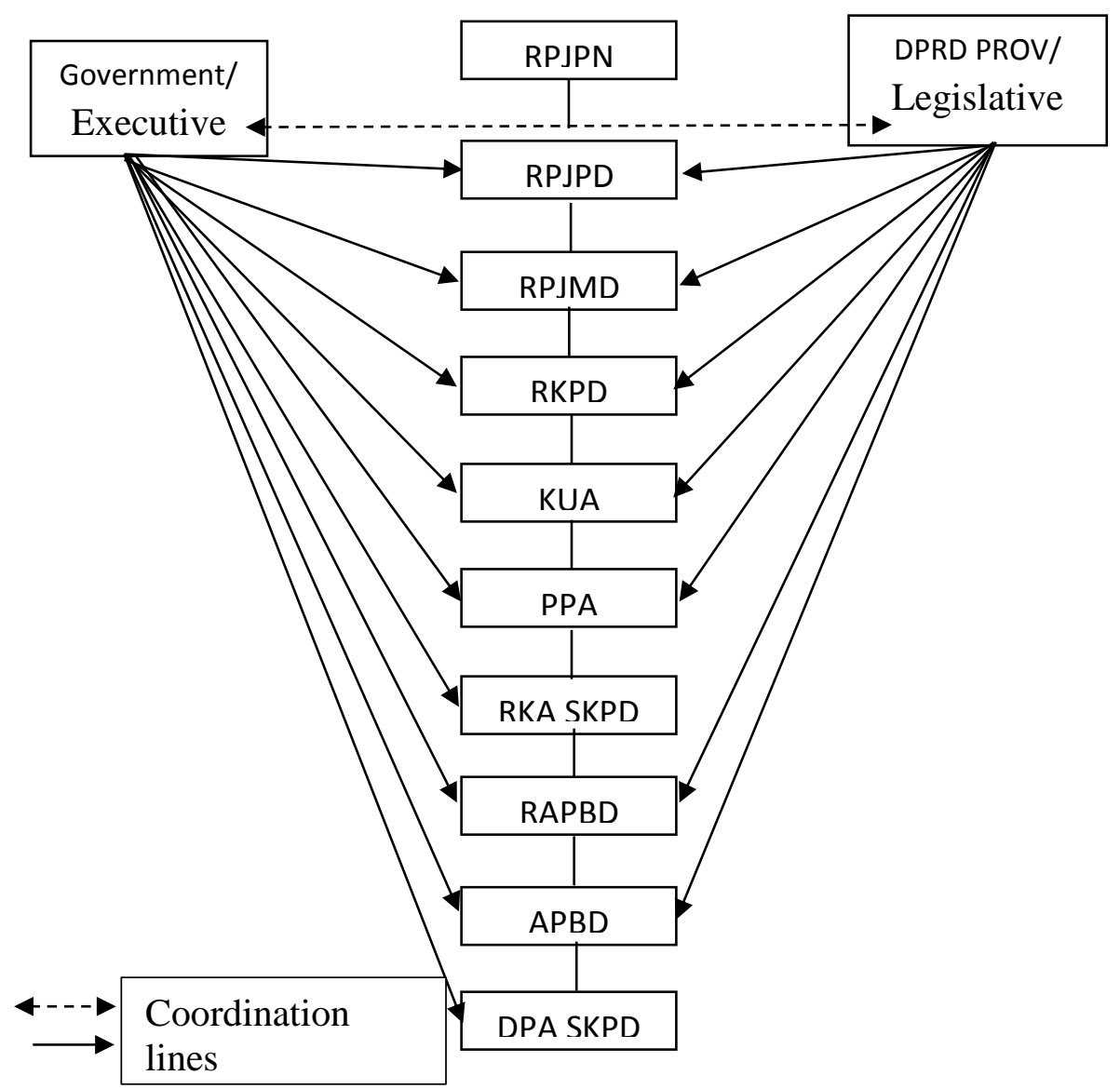

Figure: Executive and Legislative role schemes in policy making in East Java

Model "Elite Deliberatif Democratic" in Public Policy Formulation Development of Madrasah Diniyyah (non formal Islamic School) in East Java

Before the authors explain more about the model of the "democratic deliberative elite" in the public policy formulation of Madrasah diniyyahdevelopment in East Java, it is necessary to begin with the use of theoretical terms, models, and approaches in this discussion. Indeed some experts differ on the concept of policy that includes formulation, implementation, and evangelism. Some call the concept as a theory, some call it as a model and some call it an approach. The author does not intend to argue about the three terms. But the authors need to clarify here that according to some scientists who study the theory of public 
policy do not clearly distinguish between the theory of decisionmaking and the models of public policy formulation 37 .

This opinion refers, among others, to James Anderson's opinion, for example, incorporating the rational theory of comprehensive, incrementalism theory, and mixed scanning theory into decision-making theory, while system theory, group theory, elite theory, and citizen's role theory as models of approach used to review public policy. Thomas R. Dye combines incrementalism theory, comprehensive rational, elite theory, group theory, and system theory as a perspective that can be used to review public policy. Here Dye does not clearly distinguish between models, perspectives, or approaches. All three are used to exchange each other. Similarly, Charles O 'Jones, who proposed four perspectives, can be used to review public policy, namely: rationalist, incrementalism, technician, and reformist. Meanwhile, according to Lester and Stewart have different views. They distinguish models and approaches separately 38 .

While Riant Nugroho uses the term theory of policy analysis. Nugroho refers to Schermerhorn's opinion, which says that theory is a set of concepts and ideas that explains and predicts physical and social phenomena 39. Dwiyanto Indiahono, using the term model to explain the analysis of public policy. He said that the model is a simple framework that is an attempt to facilitate the explanation of a phenomenon 40. Opinion Dwiyanto Indiahono is in line with what was stated by Budi Winarno, who said that the use of models to study public policy will be very big benefits, because first, public policy is a complex, therefore, the nature of the model that simplifies the reality will be very helpful in understanding the complex reality. Both human nature are incapable of understanding complex reality without simplifying it first 41. Similarly, said Wayne Parsons, that:

37 Budi Winarno, Kebijakan Publik: Teori, Proses, dan Studi Kasus (Yogyakarta: CAPS, 2014).

38 Winarno.

39 Riant Nugroho, Public Policy: Teori, Manajemen, Dinamika, Analisis, Konvergensi dan Kimia Kebijakan (Jakarta: Elex Media Komputindo, 2014).

40 Dwiyanto Indiahono, Kebijakan Publik Berbasis Dynamic Policy Analisis (Yogyakarta: Gaya Media, 2009).

41 Winarno, Kebijakan Publik: Teori, Proses, dan Studi Kasus. 
"In analyzing public policy we must be able to organize our ideas and concepts. The world is a complex place, and to understand this complexity we need simplification. When we do simplify in order to understand the multiplicity of factors and forces that make up social problems and processes, we must construct models, map, or think in terms of metaphor" 42.

From the description of the term used in the review of public policy so diverse as presented by experts, from perspective, approach, model, to theory. However, we do not need to be trapped by this kind of difference, because each term used has its own advantages and disadvantages. We can be sure that until now there is still no single agreement among experts in defining the terms used for public policy review. Therefore, in this occasion the authors are more inclined to the term theory. Although in it is still used the term model, the approach in explaining the content of the theory of policy in question. As Leo Agustino says, that:

"As scholars of political science create theories and models to help understand and explain the decision-making process, they also develop a variety of theoretical approaches to assist us in studying and understanding the behavior of the entire political system ... the theoretical approach to be tested briefly here between: sistemic theory, group theory, elite theory, functional process theory, and institutional theories 43.

Referring to the theories of policy formulation, researchers try to draw up propositions. The proposition is meant that the formulation of East Java Provincial Government policy in the development of Madrasah diniyyah has closeness with elite theory, deliberative theory, and democratic theory.

42 Wayne Parsons, Public Policy: Pengantar, Teori dan Praktik Analisis Kebijakan (Jakarta: Kencana Prenadamedia Group, 2014).

43 Agustino, Dasar-Dasar Kebijakan Publik. 
The elite theory44 explains that the top down elites45 make public policy for implementation by public administrators to the people or society. As it is said that the big and important policy is determined by a group of elite individuals who have a very strong position 46. The closeness of policy formulation of East Java Provincial Government in development of Madrasah diniyyahwith elite theory because this policy is realization of East Java Governor and Deputy Governor (Soekarwo and Saifullah Yusuf) as the East Java bureaucracy elite. Both of these elites who are bureaucratic leaders of East Java Provincial Government currently have special attention to Madrasah Diniyyah. Special attention is then translated into the formulation of East Java longterm development policy (RPJP) and medium term (RPJM).

The formulation of elite thinking of East Java Provincial Government embodied in the vision and mission of development of East Java. The vision and mission of this development indicate that the East Java Provincial Government elite contributed significantly in the formulation of the policy of Madrasah diniyyahdevelopment in East Java.

The second theoretical footing of the formulation of this policy is deliberative theory. This theory explains that government is not the only party that determines a public policy, but the government is a processor and a legality maker of a public will. So the government and the public have equal access in determining public policy. the role of government here is more as a legality maker of "public will". While the role of policy analysts is as processor process public dialogue to produce a decision to serve as public policy 47.

C. Wright Mills Nur Syam, Model Analisis Teori Sosial (Surabaya: Putra Media Nusantrara, 2010).. The themes of power are much discussed in the sociology of structuralism and post-structuralism. Suppose Foucaoult, Derrida etc George Ritzer dan Douglas J. Goodman, Teori Sosilogi Modern (Jakarta: Kencana Prenadamedia Group, 2008)..

45 Ronald H. Chilcote, Theories of Comparative Politics: The Search for a Freedom (Jakarta: Rajawali Press, 2010).. 1956).

${ }_{46}$ C. Wright Mills, The Power Elite (New York: Oxford University Press,

47 H.A.R. Tilaar dan Riant Nugroho, Kebijakan Pendidikan: Pengantar untuk Memahami Kebijakan Pendidikan dan Kebijakan Pendidikan sebagai Kebijakan Publik (Yogyakarta: Pustaka Pelajar, 2012); Nugroho, Public 
In the context of the development policy of Madrasah diniyyahin East Java, the researcher found that this policy was formulated according to the deliberative theory approach with the argument that this policy is essentially the will of the East Java community to ensure the existence of Islamic religious education in Madrasah Diniyyah. Due to the strong desire of the East Java community for the role of the government in the management of Madrasah Diniyyah, the East Java Provincial Government through the development policy process establishes the development policy of Madrasah diniyyah in the form of quality improvement program for Madrasah Diniyah and BPPDGS teachers. This formulation is done by involving various elements of East Java society through formal, informal, and non-formal deliberations.

Democratic theory 48 is the third step in the formulation of East Java Provincial Government policy in the development of Madrasah Diniyyah. This theory explains that indeed every owner of democratic rights is included in the decision-making process. This theory is associated with the implementation of good governance. The formulation of Madrasah diniyyah development policy in East Java is the realization of the thoughts and values of democracy. The democratic values in question are mainly concerned with the involvement of the people in the formulation of policies and their impact on the community. It is as a slogan in democracy: from, by, and for the people.

It is also important to emphasize in this analysis that in some literature on public policy there is no discussion of the combination and collaboration of several theories of policy formulation. Meanwhile, the authors found that in the formulation of the policy development of Madrasah diniyyah in East Java Province there is a combination and collaboration of several theories of policy formulation; elite theory, deliberative theory, and democratic theory. So with the combination and collaboration

Policy: Teori, Manajemen, Dinamika, Analisis, Konvergensi dan Kimia Kebijakan.

48 Tilaar dan Nugroho, Kebijakan Pendidikan: Pengantar untuk Memahami Kebijakan Pendidikan dan Kebijakan Pendidikan sebagai Kebijakan Publik. 
of elite, deliberative, and democratic theorys, East Java Provincial Government successfull in formulating effective and efficient in Madrasah diniyyah development policy. And the author calls it a "elite deliberative democratic" model.

\section{Conclusion}

The "elite deliberative democratic" model in public policy formulation used by the government of East Java province generates strategic policy formulation that are relevant to the vision of development missions at the local government level. With such strategic and relevant policy formulation, a policy will be more effective and efficient in its implementation. And therefore, the relevant "elite deliberative democratic" model is developed by local governments in the formulation of public policy in the current decentralization era. The policy formulation was done through several stages. The first stage is a reading of the reality of Islamic education in East Java. The second stage is the preparation of the general policy of long-term development. The third stage of development of short-term development policy. And the fourth stage is the preparation and stipulation of Regional Regulations (Perda) on APBD, and the Governor Regulation (Pergub) based on APBD. This policy formulation model is a "democratic deliberative elite". It is a policy formulation model that combines several theories of policy formulation, such as elite theory, deliberative theory, and democratic theory.

The government of East Java province has Graduate Scholarship program (S.1) for Madrasah Diniyyah teachers. The programs supported by provision of education diniyyah and private teachers (BPPDGS). These policies are integrated into the general policy of East Java development.

\section{Bibliography}

Agustino, Leo. Dasar-Dasar Kebijakan Publik. Bandung: Alfabeta, 2012.

Ahid, Nur. "Problem Pengelolaan Madrasah Aliyah dan Solusinya." Islamica2 4, no. 2 (2010).

Azra, Azyumardi. Pendidikan Islam: Tradisi dan Modernisasi di

Tengah Tantanngan Millenium III. Jakarta: Kencana Prenadamedia Group, 2014. 
Chilcote, Ronald H. Theories of Comparative Politics: The Search for a Freedom. Jakarta: Rajawali Press, 2010.

Dunn, William N. Pengantar Analisis Kebijakan Publik. Yogyakarta: Gadjahmada University Press, 2000.

Indiahono, Dwiyanto. Kebijakan Publik Berbasis Dynamic Policy Analisis. Yogyakarta: Gaya Media, 2009.

Indonesia, Government of. National Education Standart (2005).

Indonesia, Republic of. Act. No. 23 Year 2014 (2014).

. National Education System (2003).

Mills, C. Wright. The Power Elite. New York: Oxford University Press, 1956.

Nugroho, Riant. Kebijakan Pendidikan yang Unggul: Kasus Pembangunan Pendidikan di Kabupaten Jembrana 20002006. Yogyakarta: Pustaka Pelajar, 2008.

. Public Policy: Teori, Manajemen, Dinamika, Analisis, Konvergensi dan Kimia Kebijakan. Jakarta: Elex Media Komputindo, 2014.

Parsons, Wayne. Public Policy: Pengantar, Teori dan Praktik Analisis Kebijakan. Jakarta: Kencana Prenadamedia Group, 2014.

Ritzer, George, dan Douglas J. Goodman. Teori Sosilogi Modern. Jakarta: Kencana Prenadamedia Group, 2008.

Sirozi, M. Politik Pendidikan: Dinamika Hubungan antara Kepentingan Kekuasaan dan Praktik Penyelenggaraan Pendidikan. Jakarta: Rajawali Press, 2010.

Syam, Nur. Model Analisis Teori Sosial. Surabaya: Putra Media Nusantrara, 2010.

Tilaar, H.A.R. Standarisasi Pendidikan Nasional: Suatu Tinjauan Kritis. Jakarta: Rieneka Cipta, 2006.

Tilaar, H.A.R., dan Riant Nugroho. Kebijakan Pendidikan: Pengantar untuk Memahami Kebijakan Pendidikan dan Kebijakan Pendidikan sebagai Kebijakan Publik. Yogyakarta: Pustaka Pelajar, 2012.

Winarno, Budi. Kebijakan Publik: Teori, Proses, dan Studi Kasus. Yogyakarta: CAPS, 2014.

Zainal, Veithzal Rivai, dan Fauzi Bahar. Islamic Education Management: dari Teori ke Praktek. Jakarta: Rajawali Press, 2013. 